\title{
Isolation and identification of a putative porcine transferrin receptor from Actinobacillus pleuropneumoniae biotype 1
}

\author{
M. A. Ricard, ${ }^{1} \dagger$ F. S. ARChibald ${ }^{2}$ and D. F. Niven ${ }^{1 *}$ \\ ${ }^{1}$ Department of Microbiology, Macdonald Campus of McGill University, Ste Anne de Bellevue, Québec H9X 1CO, \\ Canada \\ ${ }^{2}$ Pulp and Paper Research Institute of Canada, Pointe Claire, Québec H9R 3J9, Canada
}

(Received 20 May 1991; revised 29 August 1991; accepted 10 September 1991)

\begin{abstract}
Each of two affinity isolation methods, the first based on biotinylated porcine transferrin plus streptavidinagarose, and the second on Sepharose-coupled porcine transferrin, followed by SDS-PAGE, allowed the isolation and identification of two potential porcine-transferrin-binding polypeptides ( $\sim 64 \mathrm{kDa}$ and $99 \mathrm{kDa})$ from total membranes of Actinobacillus pleuropneumoniae grown under iron-restricted conditions. Both polypeptides were iron-repressible and were identified as potential receptor candidates as they were not isolated when biotinylated human transferrin was used instead of biotinylated porcine transferrin. The $64 \mathrm{kDa}$ polypeptide was the more easily removed from Sepharose-coupled porcine transferrin and only the $99 \mathrm{kDa}$ polypeptide appeared to be an outer-membrane protein. While these results suggest that the $99 \mathrm{kDa}$ polypeptide represents the porcine transferrin receptor of $A$. pleuropneumoniae, and that the $64 \mathrm{kDa}$ polypeptide represents an associated protein serving an accessory role, other interpretations are also possible.
\end{abstract}

\section{Introduction}

The growth of pathogens extracellularly in vivo occurs under conditions of iron restriction due to the presence of host iron-binding proteins such as transferrin and lactoferrin (e.g. Martínez et al., 1990). In response to iron-restricted growth conditions, both in vitro and in vivo, many pathogens develop high-affinity iron transport systems comprising siderophores, which are secreted and can remove iron from transferrin and lactoferrin, and iron-repressible outer-membrane proteins (IRMPs) which serve as receptors for the siderophore-iron complexes (e.g. Brown \& Williams, 1985; Griffiths, 1987). In contrast, when grown under iron-restricted conditions in vitro, Neisseria meningitidis (Archibald \& DeVoe, 1980), Neisseria gonorrhoeae (Norrod \& Williams, 1978; West \& Sparling, 1985), Pasteurella haemolytica (Ogunnariwo \& Schryvers, 1990), Haemophilus influenzae (Pidcock et al., 1988; Morton \& Williams, 1989) and also Haemophilus haemolyticus (Morton \& Williams, 1989) do not produce siderophores. Despite

† Present address: Pulp and Paper Research Institute of Canada, Pointe Claire, Québec H9R 3J9, Canada.

Abbreviations: OMP, outer-membrane protein; IRMP, iron-repressible outer-membrane protein; HRP, horseradish peroxidase. this, all of these organisms can still acquire iron from specific transferrins (Archibald \& DeVoe, 1979; Mickelsen \& Sparling, 1981; Herrington \& Sparling, 1985; Morton \& Williams, 1989; Ogunnariwo \& Schryvers, 1990), and, in some cases, from lactoferrin (Mickelsen et al., 1982; Schryvers, 1988), haemoglobin (Mickelsen \& Sparling, 1981; Pidcock et al., 1988), and haemoglobinhaptoglobin complexes (Dyer et al., 1987; Pidcock et al., 1988). Apparently, iron acquisition from transferrin and lactoferrin requires direct contact between the organisms and the proteins (Archibald \& DeVoe, 1979; Simonson $e t$ al., 1982; McKenna et al., 1988; Morton \& Williams, 1990), and involves iron-regulated receptors that exhibit specific recognition properties (Lee \& Schryvers, 1988; Schryvers, 1988; Schryvers \& Morris, 1988a, $b$; Tsai et al., 1988; Morton \& Williams, 1990; Ogunnariwo \& Schryvers, 1990); indeed, the specificities of these receptors for transferrin or lactoferrin from particular animal species afford possible explanations for the host specificities of the organisms and also for the capacities of human transferrin and lactoferrin to enhance meningococcal infections in mice (Schryvers \& Gonzalez, 1989). Such receptors are probably IRMPs, and in keeping with this suggestion, IRMPs are known to be produced in vitro by all of the above organisms (Norqvist et al., 1978; Brener et al., 1981; Mietzner et al. 1984; 
Herrington \& Sparling, 1985; Williams \& Brown, 1986; Pidcock et al., 1988; Morton \& Williams, 1989; Deneer \& Potter, 1989a) and also in vivo, by at least $N$. meningitidis (Black et al., 1986). Because of the implications for vaccine development, IRMP-receptor relationships have recently received considerable attention and as a result of such studies, specific proteins of $N$. meningitidis (Schryvers \& Morris, $1988 a, b$; Schryvers \& Lee, 1989; Ala'Aldeen et al., 1990; Griffiths et al., 1990), N. gonorrhoeae (Lee \& Bryan, 1989; Schryvers \& Lee, 1989), P. haemolytica (Ogunnariwo \& Schryvers, 1990) and $H$. influenzae (Schryvers, 1989; Morton \& Williams, 1990) have now been tentatively identified as components of transferrin or lactoferrin receptors.

Actinobacillus pleuropneumoniae biotype 1, known previously as Haemophilus pleuropneumoniae (e.g. Pohl et al., 1983), is an important respiratory tract pathogen of swine (Sebunya \& Saunders, 1983), and like the above organisms, $A$. pleuropneumoniae produces IRMPs in response to iron restriction (Deneer \& Potter, 1989b; Niven et al., 1989), and does not produce siderophores (Morton \& Williams, 1989; Niven et al., 1989). It can obtain iron from various haem compounds, including haemoglobin (Deneer \& Potter, 1989b; Niven et al., 1989 ), and produces one or more haemolysins (e.g. Frey \& Nicolet, 1988) suggesting possible mechanisms for iron acquisition. Furthermore, and perhaps more important in the initial stages of infection, $A$. pleuropneumoniae can use transferrin as an iron source and indeed, exhibits a transferrin specificity that not only correlates with host specificity but also indicates the existence of a specific transferrin receptor (Morton \& Williams, 1989; Niven et al., 1989; Morton \& Williams, 1990; Schryvers \& Gonzalez, 1990). Gonzalez et al. (1990) have recently confirmed the existence of such receptors in three field isolates of $\boldsymbol{A}$. pleuropneumoniae and demonstrated that these receptors are IRMPs of molecular mass $105 \mathrm{kDa}$. The purpose of the present study was to establish the existence and identity of such a receptor in the type strain of $A$. pleuropneumoniae which is known to produce at least three IRMPs that are potential receptor candidates (Niven et al., 1989).

\section{Methods}

Organism. A. pleuropneumoniae biotype 1 (ATCC 27088) was stored and frozen inocula were prepared as described previously (O'Reilly $e t$ al., 1984).

Chemicals. Biotinyl- $\varepsilon$-aminocaproic acid $N$-hydroxysuccinimide ester (biotin-X-NHS) and $N$-tetradecyl- $N, N$-dimethyl-3-ammonio-1-propanesulphonate (Zwittergent 3-14) were purchased from Calbiochem. Porcine serum albumin (fraction $\mathrm{V}$ powder) was from Sigma, $\mathrm{CNBr}$ activated Sepharose $4 B$ was from Pharmacia, and streptavidin-agarose was from BRL. The sources of other chemicals used, and the methods used for the isolation and purification of porcine transferrin, were as described previously (Niven et al., 1989).

Growth conditions and preparation of membranes. The growth of $A$. pleuropneumoniae under iron-replete and iron-restricted conditions has been described previously (Niven et al., 1989). Briefly, iron-replete cells were cultured in a HEPES-buffered tryptone/yeast extract medium (TYE-H) to which filter-sterilized NAD had been added to $5 \mu \mathrm{M}$. For the growth of iron-restricted cells, TYE-H was supplemented with deferrated EDDA (ethylenediamine di-o-hydroxyphenylacetic acid). Cultures were incubated at $37^{\circ} \mathrm{C}$, with agitation on a gyratory shaker (200 r.p.m.), and $1 \mathrm{~h}$ after the onset of stationary phase, the organisms were harvested by centrifugation, washed with saline $(0.85 \% \mathrm{NaCl})$, resuspended in $10 \mathrm{~mm}$-HEPES, $\mathrm{pH} 7.4$ with $\mathrm{NaOH}$, and frozen at $-20^{\circ} \mathrm{C}$.

For the preparation of total membranes, frozen suspensions were thawed, and the bacteria were either disrupted by sonication (Niven $e t$ al., 1989), or, when large quantities of membranes were required, concentrated by centrifugation $\left(20000 \mathrm{~g}, 25 \mathrm{~min}, 5^{\circ} \mathrm{C}\right)$ and disrupted by three passages through a French pressure cell operating at $12000 \mathrm{lb}$ in $^{-2}\left(\sim 8.3 \times 10^{4} \mathrm{kPa}\right)$. Unbroken cells and large debris were sedimented by centrifugation $\left(16000 \mathrm{~g}, 10 \mathrm{~min}, 5^{\circ} \mathrm{C}\right)$ and the top $80 \%$ of each supernatant fraction was carefully removed and subjected to high-speed centrifugation $\left(180000 \mathrm{~g}, 1 \mathrm{~h}, 5^{\circ} \mathrm{C}\right)$. The resulting pellets (total membranes) were resuspended with small volumes of $10 \mathrm{~mm}$ HEPES, pH 7.4. Outer membranes were prepared from total membranes by means of Sarkosyl (sodium $N$-lauroyl sarcosine) extraction (Niven et al., 1989).

Preparation of iron-binding proteins. Porcine and human transferrins were saturated with iron and then dialysed as described by Caldwell \& Archibald (1987).

Preparation of biotinylated proteins. Porcine transferrin, human transferrin and porcine albumin were biotinylated as described for lactoferrin by Schryvers \& Morris $(1988 b)$ but with some minor modifications. The iron-saturated transferrins $\left(5 \mathrm{mg}\right.$ protein $\left.\mathrm{ml}^{-1}\right)$ and porcine albumin ( $5 \mathrm{mg} \mathrm{ml}^{-1}$ in $\left.50 \mathrm{mM}-\mathrm{Tris} / \mathrm{HCl}, \mathrm{pH} 7.5\right)$ were dialysed overnight against $50 \mathrm{~mm}$-Tris/ $\mathrm{HCl}, \mathrm{pH} 7.5\left(21 ; 4^{\circ} \mathrm{C}\right)$. Biotin-X-NHS $(7.2 \mathrm{mg})$ was dissolved in $500 \mu \mathrm{l}$ dimethylformamide and $160 \mu \mathrm{l}$ of this solution $\left[16 \mu \mathrm{l}(\mathrm{mg} \text { protein })^{-1}\right]$ were added to each dialysate. The resulting mixtures were incubated for $2 \mathrm{~h}$ at $4{ }^{\circ} \mathrm{C}$ (with gentle agitation), the reactions were stopped by addition of $1 \mathrm{ml}$ glycine (10 $\left.\mathrm{mg} \mathrm{ml}^{-1}\right)$ to each solution, and incubation was continued for a further $2 \mathrm{~h}$. The biotinylated proteins were then dialysed overnight against $10 \mathrm{mM}-\mathrm{NaCl}, 50 \mathrm{~mm}-\mathrm{Tris} / \mathrm{HCl}, \mathrm{pH} 7.5(1)$, with three changes; $4{ }^{\circ} \mathrm{C}$ ) and stored as necessary, at $-20^{\circ} \mathrm{C}$.

Isolation of transferrin-binding polypeptides using biotinylated porcine transferrin. Transferrin-binding polypeptides were isolated by the batch affinity procedure described by Schryvers $\&$ Morris (1988b) but using $200 \mu \mathrm{g}$ of biotinylated protein for each extraction. Briefly, total membranes $(750 \mu \mathrm{g}$ protein) from $A$. pleuropneumoniae grown under iron-replete or iron-restricted conditions were mixed with $200 \mu \mathrm{g}$ of biotinylated protein (porcine or human transferrin, or porcine albumin) and the volume brought to $1 \mathrm{ml}$ with $100 \mathrm{mM}-\mathrm{NaCl}, 50 \mathrm{~mm}$ Tris/ $\mathrm{HCl}, \mathrm{pH} \mathrm{8.0}$; for control samples, the biotinylated proteins were omitted. The samples were incubated $\left(1 \mathrm{~h}, 37^{\circ} \mathrm{C}\right.$, gentle agitation) and then centrifuged $(16000 \mathrm{~g}, 10 \mathrm{~min}$; Eppendorf microcentrifuge). The supernatant fractions were removed carefully and each pellet was resuspended in $1 \mathrm{ml} 0.75 \%(\mathrm{w} / \mathrm{v})$ Sarkosyl in $100 \mathrm{~mm}-\mathrm{NaCl}, 10 \mathrm{~mm}$ EDTA, $50 \mathrm{~mm}$-Tris/ $\mathrm{HCl}, \mathrm{pH} 8 \cdot 0$. Streptavidin-agarose (diluted 2-fold with water; $100 \mu \mathrm{l}$ ) was added to each tube and the samples were mixed and incubated $\left(1 \mathrm{~h}, 20^{\circ} \mathrm{C}\right)$. The samples were then centrifuged $(750 \mathrm{~g}$, $3 \mathrm{~min}, 20^{\circ} \mathrm{C}$ ) and the affinity resin pellets were washed (by successive cycles of resuspension in buffer, incubation for $10 \mathrm{~min}$ at $20^{\circ} \mathrm{C}$, and 
centrifugation) using one of three wash systems. Wash system 1 consisted of three washes in $0.5 \%$ Sarkosyl, $100 \mathrm{mM}-\mathrm{NaCl}, 10 \mathrm{mM}$ EDTA, $50 \mathrm{~mm}$-Tris $/ \mathrm{HCl}$, pH 8.0 , followed by two washes in $100 \mathrm{~mm}$ $\mathrm{NaCl}, 50 \mathrm{~mm}-\mathrm{Tris} / \mathrm{HCl}, \mathrm{pH} \mathrm{8.0.} \mathrm{Wash} \mathrm{system} 2$ consisted of three washes in $0.5 \%$ Sarkosyl, $1 \mathrm{M}-\mathrm{NaCl}, 10 \mathrm{~mm}$-EDTA, $50 \mathrm{~mm}$-Tris $/ \mathrm{HCl}$,

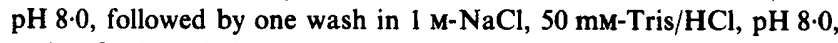
and a final wash in $100 \mathrm{~mm}-\mathrm{NaCl}, 50 \mathrm{~mm}-\mathrm{Tris} / \mathrm{HCl}, \mathrm{pH} 8.0$. Wash system 3 consisted of three washes in $0.5 \%$ Sarkosyl, $1 \mathrm{M}-\mathrm{NaCl}, 10 \mathrm{mM}$ EDTA, 250 mM-guanidine $\mathrm{HCl}, 50 \mathrm{~mm}$-Tris/ $\mathrm{HCl}, \mathrm{pH} \mathrm{8.0,} \mathrm{followed} \mathrm{by}$ one wash in $1 \mathrm{M}-\mathrm{NaCl}, 250 \mathrm{~mm}$-guanidine $\mathrm{HCl}, 50 \mathrm{~mm}$-Tris $/ \mathrm{HCl}$, $\mathrm{pH} 8.0$, and a final wash as in wash system 2 .

To identify the isolated polypeptides, the washed affinity resin pellets were resuspended in $200 \mu \mathrm{l}$ of a sample buffer containing $2 \%$ $(w / v)$ SDS, $30 \%(v / v)$ glycerol and $0.1 \%(w / v)$ bromophenol blue in $200 \mathrm{~mm}$-Tris/ $\mathrm{HCl}, \mathrm{pH} 6 \cdot 8$. The samples tubes were immersed in boiling water for $5 \mathrm{~min}$, cooled on ice, and centrifuged $(750 \mathrm{~g}, 3 \mathrm{~min})$. The supernatant fractions were then transferred to clean tubes, 2mercaptoethanol was added (to $1.4 \mathrm{M}$ ), and following incubation $\left(15 \mathrm{~min}, 20^{\circ} \mathrm{C}\right.$ ), the samples were mixed thoroughly and $50 \mu \mathrm{l}$ aliquots were subjected to SDS-PAGE $(\sim 16 \mathrm{~h} ; 10 \%$, w/v, acrylamide separating gels) essentially as described by Niven et al. (1989). The gels were fixed for $24 \mathrm{~h}$ in $10 \%(\mathrm{v} / \mathrm{v})$ acetic acid, $50 \%(\mathrm{v} / \mathrm{v})$ ethanol and the separated polypeptides visualized by means of silver staining according to the method of Oakley et al. (1980) except that development of the stain was stopped with $0.35 \%(\mathrm{v} / \mathrm{v})$ acetic acid.

For SDS-PAGE, outer membranes were prepared similarly, and electrophoresis ( $1 \mu \mathrm{g}$ protein per lane) and staining were done as described above.

Preparation of Sepharose-coupled porcine transferrin. Sepharosecoupled porcine transferrin was prepared according to the instructions supplied with the CNBr-activated Sepharose 4B. Briefly, CNBractivated Sepharose 4B $(3.2 \mathrm{~g})$ was rehydrated and washed of additives in a sintered glass funnel using $800 \mathrm{ml} 1 \mathrm{mM}-\mathrm{HCl}$. Following a rinse with $60 \mathrm{ml} 500 \mathrm{~mm}-\mathrm{NaCl}, 100 \mathrm{~mm}-\mathrm{NaHCO}_{3}, \mathrm{pH} 8.3$ with $\mathrm{NaOH}$ (coupling buffer), the swelled gel was transferred quickly to a $50 \mathrm{ml}$ flask containing $95 \mathrm{mg}$ of iron-saturated porcine transferrin in $24 \mathrm{ml}$ of coupling buffer. This mixture was incubated for $2 \mathrm{~h}$ at $20^{\circ} \mathrm{C}$, with gentle agitation on a gyratory shaker, and the resulting Sepharosecoupled porcine transferrin was rinsed of unbound ligand with $60 \mathrm{ml}$ of coupling buffer, transferred to $24 \mathrm{ml}$ of blocking buffer $(500 \mathrm{~mm}-\mathrm{NaCl}$, $200 \mathrm{~mm}$-glycine, $\mathrm{pH} 8.0$ with $\mathrm{NaOH}$ ), and incubated for a further $2 \mathrm{~h}$. The slurry was then used to pack a small column $(1 \times 10 \mathrm{~cm})$ and excess unbound ligand was removed by three cycles of washing, each consisting of $30 \mathrm{ml} 500 \mathrm{mM}-\mathrm{NaCl}, 100 \mathrm{~mm}$-sodium acetate, $\mathrm{pH} 4 \cdot 0$ with $\mathrm{HCl}$, followed by $30 \mathrm{ml} 500 \mathrm{~mm}-\mathrm{NaCl}, 100 \mathrm{~mm}-\mathrm{Tris} / \mathrm{HCl}, \mathrm{pH} 8.0$. The porcine transferrin was then resaturated with iron by passing through the column, 3 bed vols of a solution of $\mathrm{FeCl}_{3}\left(5 \mu \mathrm{g} \mathrm{Fe} \mathrm{ml}{ }^{-1}\right)$ in $200 \mathrm{mM}$ Tris, $20 \mathrm{~mm}-\mathrm{NaHCO}_{3}$, $\mathrm{pH} 7 \cdot 4$.

Isolation of transferrin-binding polypeptides using Sepharose-coupled porcine transferrin. Total membranes $(60 \mathrm{mg}$ protein in $2 \mathrm{ml} 10 \mathrm{~mm}$ HEPES, pH 7.4) from organisms grown under iron-replete or ironrestricted conditions were added to $41 \mathrm{ml} 100 \mathrm{~mm}-\mathrm{NaCl}, 50 \mathrm{~mm}$ Tris/ $\mathrm{HCl}$, pH 8.0, containing $1.8 \mathrm{~g}$ (wet wt) of Sepharose-coupled porcine transferrin, and the mixture was incubated for $1 \mathrm{~h}$ at $37^{\circ} \mathrm{C}$, with gentle agitation. Zwittergent (3-14), or Sarkosyl, and EDTA were added to give final concentrations of $2 \%(w / v), 0.75 \%(w / v)$ and $10 \mathrm{mM}$, respectively, and incubation was continued for $1 \mathrm{~h}$ at $20^{\circ} \mathrm{C}$. The beads were collected in a Poly-Prep chromatography column $(10 \mathrm{ml}$; Bio$\mathrm{Rad}$ ) and rinsed with 3 bed vols $100 \mathrm{mM}-\mathrm{NaCl}, 10 \mathrm{~mm}-\mathrm{EDTA}, 50 \mathrm{mM}-$ Tris $/ \mathrm{HCl}, \mathrm{pH} 8.0$, containing $0.5 \%(\mathrm{w} / \mathrm{v})$ of either Zwittergent or Sarkosyl (100 mm-NaCl-rinse buffer), as appropriate. Bound proteins were eluted with either 3 bed vols $2.5 \mathrm{M}-\mathrm{NaCl}$-rinse buffer or with 3 bed vols of each of a series of $\mathrm{NaCl}(0.5,1 \cdot 0,1 \cdot 5,2 \cdot 0,2 \cdot 5,3.0 \mathrm{M})$-rinse buffers followed by 3 bed vols of each of a series of urea solutions $(2,4,6,8 \mathrm{M}$; each pH 7.0 with $\mathrm{HCl}$ ) containing $0.5 \%(\mathrm{w} / \mathrm{v})$ of either $\mathrm{Zwittergent}$ or Sarkosyl, as appropriate. Fractions $(1 \mathrm{ml})$ were collected and elution was monitored by recording the absorbance of each fraction at $280 \mathrm{~nm}$; protein-containing fractions were then pooled, as appropriate, and fractions containing $\mathrm{NaCl}$ at concentrations of $2 \mathrm{M}$ or greater were dialysed overnight against $50 \mathrm{~mm}-\mathrm{Tris} / \mathrm{HCl}, \mathrm{pH} 6.8$, containing $0.05 \%$ $(\mathrm{w} / \mathrm{v})$ of either Zwittergent or Sarkosyl $\left(21 ; 4^{\circ} \mathrm{C}\right)$.

To identify the isolated proteins, the above samples were mixed with sample buffer (Niven et al., 1989), and appropriate volumes were subjected to SDS-PAGE $(\sim 16 \mathrm{~h} ; 10 \%, \mathrm{w} / \mathrm{v}$, acrylamide separating gels), essentially as described by Niven et al. (1989). Outer membranes ( $1 \mu \mathrm{g}$ protein per lane) were treated similarly, and in all cases, the separated polypeptides were visualized by means of silver staining (Harlow \& Lane, 1988).

In some experiments, the method of Blake \& Gotschlich (1982) was used to solubilize total membranes prior to their contact with Sepharose-coupled porcine transferrin. Total membranes $(200 \mathrm{mg}$ protein in $5 \mathrm{ml} 10 \mathrm{mM}$-HEPES, pH 7.4) were mixed with $5 \mathrm{ml} 500 \mathrm{~mm}$ $\mathrm{NaCl}, 10 \mathrm{~mm}$-EDTA, $50 \mathrm{~mm}$-Tris/HCl, pH 8.0, containing $5 \%(\mathrm{w} / \mathrm{v})$ Zwittergent (extraction buffer) and incubated, with agitation, for $1 \mathrm{~h}$ at $37^{\circ} \mathrm{C}$. The mixture was centrifuged $\left(16000 \mathrm{~g}, 10 \mathrm{~min}, 5^{\circ} \mathrm{C}\right)$, the supernatant was retained, and the pellet was re-extracted (as above) with $10 \mathrm{ml}$ of extraction buffer. The two supernatant fractions were then pooled and dialysed overnight against $0.05 \%(w / v) Z$ wittergent in 10 mM-EDTA, 50 mM-Tris/HCl, pH 8.0 (Tris-Z3,14 buffer; $21 ; 4^{\circ} \mathrm{C}$ ). The dialysate was applied to a column of Sepharose-coupled porcine transferrin $\left(1 \times 10 \mathrm{~cm} ; 4^{\circ} \mathrm{C}\right)$ pre-equilibrated with Tris-Z3,14 buffer, and proteins were eluted by a gradient obtained by mixing $500 \mathrm{ml}$ each of Tris- $\mathrm{Z3}, 14$ buffer and $0.3 \mathrm{M}-\mathrm{NaCl}$ in Tris-Z3,14 buffer, followed by a second gradient obtained by mixing $500 \mathrm{ml}$ each of $0.3 \mathrm{M}-\mathrm{NaCl}$ in Tris$\mathrm{Z3,14}$ buffer and $3 \mathrm{M}-\mathrm{NaCl}$ in Tris- $\mathrm{Z3}, 14$ buffer, and finally by the passage of $60 \mathrm{ml} 6 \mathrm{M}$-urea ( $\mathrm{pH} 7.0$ with $\mathrm{HCl}$ ) containing $0.05 \%(\mathrm{w} / \mathrm{v})$ Zwittergent. Elution was monitored as described above, and proteincontaining fractions were pooled, as appropriate, dialysed as necessary to reduce the $\mathrm{NaCl}$ concentration, and then analysed by means of SDSPAGE.

Estimation of protein concentrations. All protein concentrations were estimated using the method of Peterson (1977) and bovine serum albumin as a standard.

\section{Results}

Our initial attempts at the isolation and identification of a transferrin receptor from $A$. pleuropneumoniae were based on methods described by Schryvers \& Morris $(1988 a)$ and involved the separation of outer membrane, and also total membrane polypeptides by means of SDSPAGE followed by electroblot analysis with horseradish peroxidase (HRP)-conjugated porcine transferrin. However, the results from these studies were inconclusive due to non-specific binding reactions and consequently, this approach was abandoned in favour of receptor isolation by means of affinity chromatography followed by identification by means of SDS-PAGE.

Two affinity isolation procedures were used. The first was based on that used by Schryvers \& Morris $(1988 b)$ to isolate the lactoferrin-binding protein from $N$. meningitidis. Briefly, total membranes from $A$. pleuropneumoniae grown under iron-restricted or iron-replete conditions 


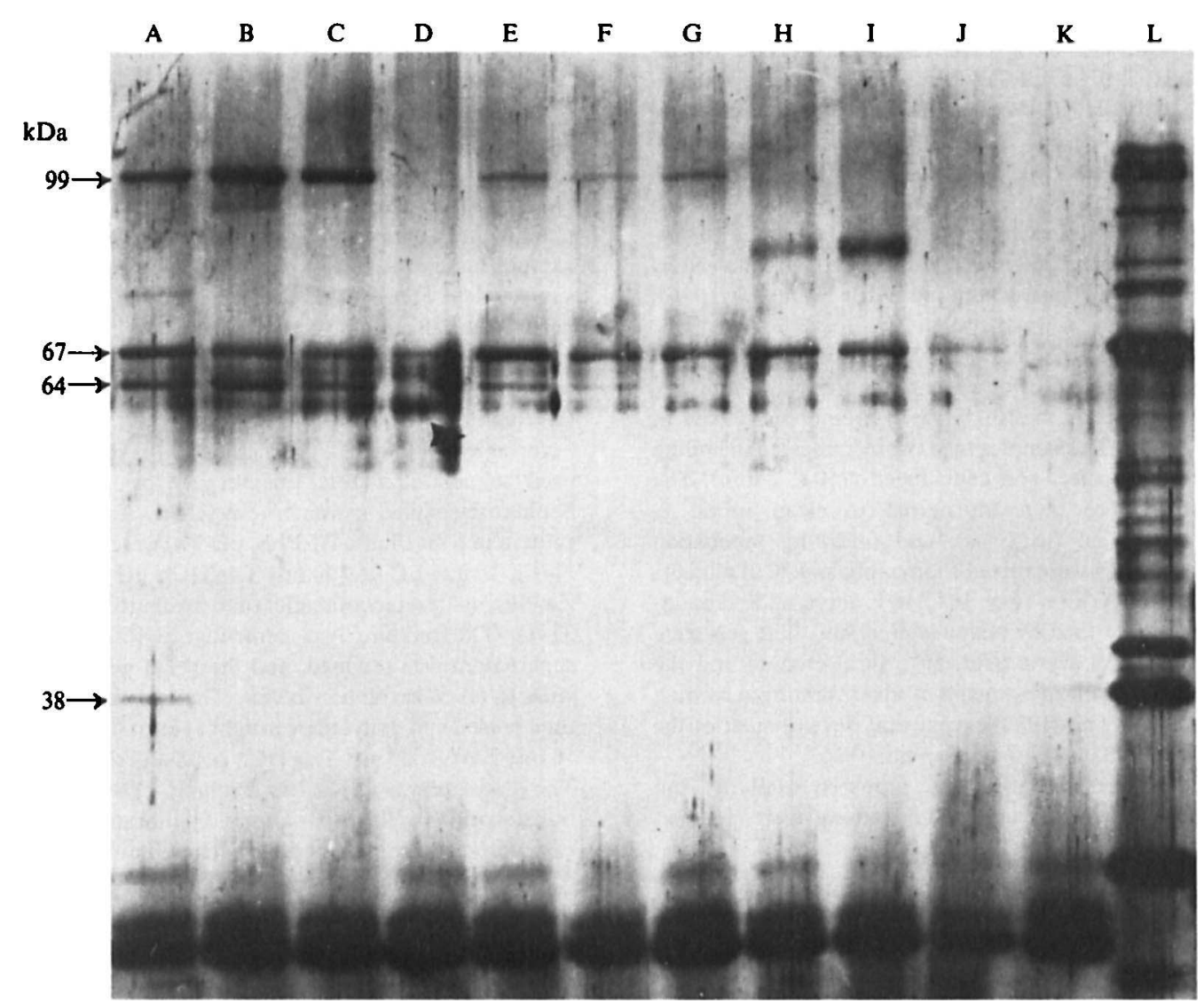

Fig. 1. Identification of transferrin-binding polypeptides isolated from $A$. pleuropneumoniae by means of biotinylated porcine transferrin. Lanes A-J, affinity-isolated polypeptides from total membranes prepared from iron-restricted cells; lane $K$, affinityisolated polypeptides from total membranes prepared from iron-replete cells; lane $\mathrm{L}$, outer-membrane polypeptides from iron-restricted cells. The biotinylated proteins and the wash systems were as follows: lanes A and $\mathrm{K}$, porcine transferrin, wash 1; lane $\mathrm{B}$, porcine transferrin, wash 2 ; lane $C$, porcine transferrin, wash 3 ; lane $D$, no biotinylated protein, wash 1 ; lane E, porcine albumin, wash 1 ; lane F, porcine albumin, wash 2 ; lane G, porcine albumin, wash 3; lane $H$, human transferrin, wash 1; lane I, human transferrin, wash 2; lane J, human transferrin, wash 3. See Methods and Results for additional details; the numbers refer to the relative molecular sizes $(\mathrm{kDa})$ of the indicated polypeptides.

were incubated in the presence or absence of a biotinylated protein. The detergent Sarkosyl was then added followed by streptavidin-agarose. The resulting complexes, consisting of streptavidin-agarose, biotinylated protein and bound proteins, were harvested by centrifugation, washed according to one of three protocols, and then boiled to release the bound proteins for analysis by means of SDS-PAGE. Typical results are presented in Fig. 1 (lanes A-K). Lanes A-C (Fig. 1) illustrate that irrespective of the wash protocol, the use of biotinylated porcine transferrin as binding ligand allowed the isolation of several polypeptides from membranes derived from iron-restricted organisms. Of these polypeptides, the 64 and $99 \mathrm{kDa}$ polypeptides were of particular interest as these polypeptides were not isolated when the biotinylated porcine transferrin was omitted (Fig. 1, lane D), they were not isolated when the biotinylated porcine transferrin was replaced with biotinylated human transferrin (Fig. 1, lanes $\mathrm{H}-\mathrm{J}$ ), and they were not isolated when membranes from ironreplete organisms were used (Fig. 1, lane $\mathrm{K}$ ). While these results indicated that the 64 and $99 \mathrm{kDa}$ polypeptides were specific, iron-repressible, porcine-transferrin-binding polypeptides, it was appreciated that our porcine transferrin preparations are occasionally contaminated with trace amounts of porcine serum albumin. To ensure that the 64 and $99 \mathrm{kDa}$ polypeptides were indeed transferrin-binding polypeptides rather than albuminbinding polypeptides, control experiments were done using biotinylated porcine albumin as binding ligand. The resulting polypeptide profiles (Fig. 1, lanes E-G) revealed that while biotinylated porcine albumin (Fig. 1, lanes $\mathrm{E}-\mathrm{G}$ ) and biotinylated porcine transferrin (Fig. 1, lanes $\mathrm{A}-\mathrm{C}$ ) were associated with the isolation of the same polypeptides, substantially smaller amounts of the 64 and $99 \mathrm{kDa}$ polypeptides were isolated when the binding 
ligand was biotinylated porcine albumin. While these results per se indicated strongly that the 64 and $99 \mathrm{kDa}$ polypeptides were transferrin-binding polypeptides rather than albumin-binding polypeptides, the albuminassociated isolation of these polypeptides remained somewhat enigmatic. However, just as our porcine transferrin preparations are occasionally contaminated with porcine albumin, iron-loading studies (not presented) revealed that, conversely, the commercial porcine serum albumin preparation was contaminated with an iron-binding protein, presumably porcine transferrin; in effect, it would appear that the isolation of the 64 and $99 \mathrm{kDa}$ polypeptides was indeed due to a specific interaction(s) with porcine transferrin.

Fig. 1 also allows the affinity-isolated polypeptides (lanes A-K) to be compared with the outer-membrane polypeptides (OMPs) from iron-restricted organisms (lane L). Interestingly, the $99 \mathrm{kDa}$ polypeptide (Fig. 1, lanes A-C), which is iron-repressible (above), comigrated with an OMP (Fig. 1, lane $\mathrm{L}$ ) which is known to be an IRMP (Fig. 2, lanes A and B; Niven et al., 1989). While it is tempting to speculate that these polypeptides are identical, and an outer-membrane location would be compatible with a transferrin-binding capability, the $64 \mathrm{kDa}$ polypeptide (Fig. 1, lanes $\mathrm{A}-\mathrm{C}$ ), which is also iron-repressible (above), did not appear to have an outermembrane counterpart (Fig. 1, lane L). This, however, may only indicate that the $64 \mathrm{kDa}$ polypeptide represents a peripheral OMP that is released during Sarkosylextraction of total membranes; in effect, the transferrinassociated isolation of the $64 \mathrm{kDa}$ polypeptide and its absence from Sarkosyl-extracted outer membranes are not mutually exclusive.

Of the other polypeptides isolated (Fig. 1, lanes A-K), the $67 \mathrm{kDa}$ polypeptide is also notable. Although it was isolated under all conditions (Fig. 1, lanes A-K), the relative intensities of the polypeptide bands indicate that while the $67 \mathrm{kDa}$ polypeptide can bind to streptavidinagarose (Fig. 1, lane D), it may also be capable of binding to some component(s) present in the biotinylated transferrin (Fig. 1, lanes $\mathrm{A}$ and $\mathrm{H}$ ) and biotinylated albumin (Fig. 1, lane E) preparations. While this component(s) remains to be identified, it is interesting to note that the $67 \mathrm{kDa}$ polypeptide co-migrated with an OMP (Fig. 1, lane L) and moreover, that the production of both appeared to be iron-regulated (Fig. 1, cf. lanes A and $\mathrm{K}$; Fig. 2, cf. lanes A and B). On the other hand, previous studies with the same strain of $A$. pleuropneumoniae have demonstrated that the production of a $69 \mathrm{kDa}$ OMP (equivalent to our $67 \mathrm{kDa}$ OMP) is enhanced not only by reducing the supply of iron to the organism (Niven et al., 1989) but also by reducing the pyridine nucleotide supply or the supply of glucose (T. O'Reilly, D. F. Niven \& M. R. W. Brown, unpublished).

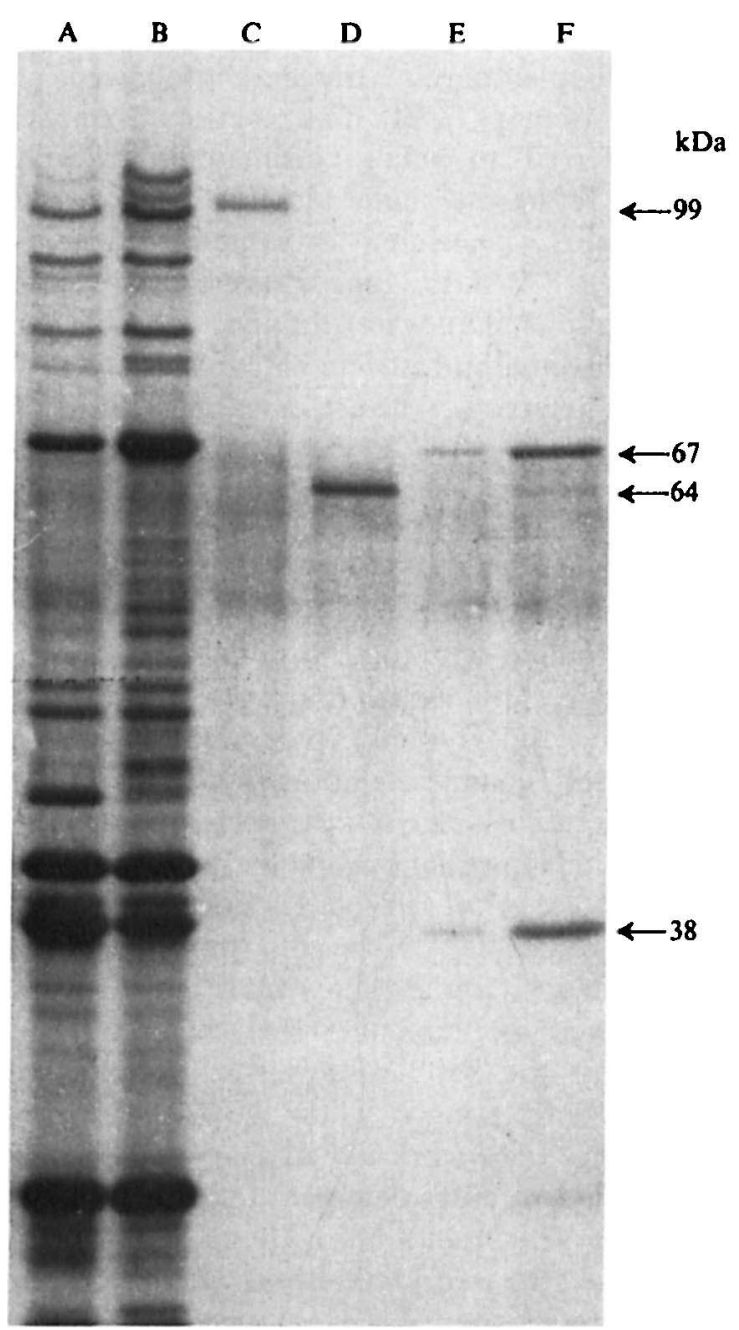

Fig. 2. Identification of transferrin-binding polypeptides isolated from A. pleuropneumoniae by means of Sepharose-coupled porcine transferrin. Lane A, outer-membrane polypeptides from iron-replete cells; lane $B$, outer-membrane polypeptides from iron-restricted cells; lanes $C-F$, affinity-isolated materials from iron-restricted total membranes that were either (lanes C, E and F) treated with Sepharose-transferrin and then with Sarkosyl, or (lane D) solubilized with Zwittergent and then applied to a column of Sepharose-transferrin. The bound proteins were eluted from the affinity resins as follows: lane $C$, when a solution containing $2 \mathrm{M}$-urea was followed by one containing $4 \mathrm{M}$-urea; lane $\mathrm{D}$, by a gradient of $\mathrm{NaCl}(0.3-3.0 \mathrm{M})$ in buffer; lane $\mathrm{E}$, when rinse buffer was followed by a buffer solution containing $0.5 \mathrm{M}-\mathrm{NaCl}$; lane $\mathrm{F}$, when rinse buffer was followed by a buffer solution containing $2 \cdot 5 \mathrm{M}-\mathrm{NaCl}$. See Methods and Results for additional details; the numbers refer to the relative molecular sizes $(\mathrm{kDa})$ of the indicated polypeptides.

In effect, if the $67 \mathrm{kDa}$ affinity-isolated polypeptide and the $67 \mathrm{kDa}$ OMP are identical, it is highly probable that the $67 \mathrm{kDa}$ polypeptide, rather than being involved specifically in iron acquisition from transferrin, or from some other iron source, plays a somewhat general role in the outer membrane of $A$. pleuropneumoniae.

In the second affinity isolation procedure, total membranes from $A$. pleuropneumoniae grown under iron- 
restricted or iron-replete conditions were incubated with Sepharose-coupled porcine transferrin followed by Sarkosyl or Zwittergent (3-14). The reaction mixtures were then transferred to small chromatography columns where the Sepharose materials were rinsed and the bound proteins were eluted for subsequent analysis by means of SDS-PAGE. Fig. 2 (lanes C, E and F) illustrates results that were obtained when the membranes were from iron-restricted organisms and Sarkosyl was used as detergent. The use of a single elution buffer containing $2.5 \mathrm{M}-\mathrm{NaCl}$ allowed the elution of polypeptides of 38 and $67 \mathrm{kDa}$ along with relatively smaller amounts of several other polypeptides including a polypeptide of $64 \mathrm{kDa}$ (Fig. 2, lane F). Interestingly, when a step gradient of $\mathrm{NaCl}$, rather than a single elution buffer, was used to wash the affinity column, many of the above polypeptides were found to elute at $\mathrm{NaCl}$ concentrations of less than $2.5 \mathrm{M}$ (e.g. Fig. 2, lane E); on the other hand, complete elution of the $6 \mathrm{kDa}$ polypeptide required the passage of a buffer solution containing $3 \mathrm{M}-\mathrm{NaCl}$ (not shown) and when the $\mathrm{NaCl}$ gradient was followed by one of urea, a $99 \mathrm{kDa}$ polypeptide was also isolated (Fig. 2, lane C). Results that were similar to those depicted in Fig. 2, lanes C, E and F, were also obtained when Zwittergent, rather than Sarkosyl, was used to treat the Sepharose-transferrin-treated membranes and interestingly, while the reverse procedure does not appear to work effectively when Sarkosyl or Triton X-100 is used as detergent (Schryvers \& Morris, $1988 b$; Schryvers, 1989), all of the above polypeptides were also isolated (see Methods for elution procedures) when membranes from A.pleuropneumoniae were treated with Zwittergent prior to their contact with the Sepharose-coupled porcine transferrin (e.g. Fig. 2, lane D); it is therefore conceivable that by using Zwittergent as the membrane-solubilizing agent, it may be possible to use conventional affinity chromatography, routinely, for the isolation and purification of bacterial receptor proteins. Finally, the 64 and 99 kDa polypeptides (Fig. 2) were found to be iron-repressible in that they, unlike the $67 \mathrm{kDa}$ polypeptide, were not isolated when the membranes were from iron-replete organisms (not shown), and based on this information, as well as the molecular sizes and binding characteristics of the isolated polypeptides, it was concluded that the 64 and $99 \mathrm{kDa}$ polypeptides that were isolated by means of Sepharosecoupled porcine transferrin, and those that were isolated by means of biotinylated porcine transferrin, were the same, porcine-specific, transferrin-binding polypeptides.

\section{Discussion}

Affinity isolation procedures have recently allowed the successful isolation of iron-repressible, specifically host- transferrin-binding polypeptides from a variety of strains of $N$. meningitidis, $N$. gonorrhoeae, $H$. influenzae and P. haemolytica (Schryvers \& Morris, $1988 b$; Lee \& Bryan, 1989; Schryvers, 1989; Schryvers \& Lee, 1989; Ogunnariwo \& Schryvers, 1990). Typically, the isolated polypeptides have included one of high molecular mass (94-106 kDa) and one or more of lower molecular mass $(58-86 \mathrm{kDa})$ and it has been suggested that these polypeptides may exist in situ in the form of iron acquisition complexes (Lee \& Bryan, 1989; Schryvers, 1989; Schryvers \& Lee, 1989; Ogunnariwo \& Schryvers, 1990). Regarding the capacities of these polypeptides to function as transferrin receptors, considerable attention has been focussed on the affinity-isolated polypeptides from $N$. meningitidis $\mathrm{B} 16 \mathrm{~B} 6$ and $H$. influenzae $\mathrm{KC} 548$ (Schryvers, 1989; Schryvers \& Lee, 1989). Each of these organisms yielded two such polypeptides and following SDS-PAGE and electoblotting, the low molecular mass polypeptides, but not the high molecular mass polypeptides, were found to be capable of binding HRPtransferrin. Interestingly, however, it would appear that the high molecular mass polypeptides are also capable of direct binding to transferrin as these polypeptides were the last polypeptides to be eluted from the transferrinaffinity resins (Schryvers, 1989; Schryvers \& Lee, 1989). Although it would appear, therefore, that the transferrin receptors of $N$. meningitidis and $H$. influenzae may comprise both low molecular mass and high molecular mass polypeptides, the capacity to bind HRP-transferrin after SDS-PAGE and electroblotting is exhibited by a low molecular mass polypeptide from each of only some strains of these organisms (Schryvers, 1989; Schryvers \& Lee, 1989), and to further complicate the issue, the results of Tsai et al. (1988) indicate that such a polypeptide may not be necessary for receptor function. In effect, the nature of the transferrin receptors of these organisms remains uncertain.

In the present study, each of two affinity isolation methods allowed the isolation of two potentially transferrin-binding polypeptides ( $\sim 99 \mathrm{kDa}$ and $64 \mathrm{kDa})$ from the type strain of $A$. pleuropneumoniae biotype 1 (Figs 1 and 2). This organism acquires transferrin-bound iron by means of a non-siderophore-mediated, porcine-transferrin-specific mechanism (Niven et al., 1989) and in keeping with this fact, both polypeptides were isolated specifically with porcine transferrin (Fig. 1). These results are similar to those obtained recently in similar studies with three other strains of $\boldsymbol{A}$. pleuropneumoniae (Gonzalez et al., 1990); each of these strains also yielded two, specifically porcine-transferrin-binding polypeptides. There are, however, slight differences in the relative molecular sizes of the low molecular mass polypeptides isolated from the different strains, the values ranging from $56 \mathrm{kDa}$ in strain AP7 (Gonzalez et al., 1990) to $64 \mathrm{kDa}$ in the type strain (this study). 
Interestingly, such interstrain molecular size heterogeneity has also been observed with the analogous low molecular mass polypeptides affinity-isolated with human transferrin from strains of $N$. gonorrhoeae and $N$. meningitidis (Lee \& Bryan, 1989; Schryvers \& Lee, 1989). On the other hand, note that the high molecular mass transferrin-binding polypeptides from $N$. gonorrhoeae and $N$. meningitidis are very similar in size (Lee \& Bryan, 1989; Schryvers \& Lee, 1989) and it would appear that this is also the case in strains of $A$. pleuropneumoniae; although the high molecular mass polypeptides from strains AP7, AP78 and $\mathrm{H} 49$ were reported to have molecular masses of $105 \mathrm{kDa}$ (Gonzalez et al., 1990), the data presented by Gonzalez et al. (1990) and the fact that the polypeptides in question co-migrated with the high molecular mass transferrin-binding polypeptide from $N$. meningitidis B16B6 (Gonzalez et al., 1990) indicate a molecular mass of closer to $98 \mathrm{kDa}$ (see Schryvers \& Lee, $1989)$ and close to that reported here $(99 \mathrm{kDa})$.

Regarding the capacities of these polypeptides to function as transferrin receptors in A. pleuropneumoniae, all of the polypeptides that were affinity-isolated from strains AP7, AP78 and H49 were shown to be IRMPs, and following SDS-PAGE and electroblotting, the low molecular mass polypeptides were shown to be capable of binding HRP-transferrin (Gonzalez et al., 1990). While the $99 \mathrm{kDa}$ polypeptide from the type strain is almost certainly also an IRMP, the in situ location of the $64 \mathrm{kDa}$ polypeptide, which is also iron-repressible, is much less obvious as this polypeptide was absent from Sarkosyl-extracted outer membranes (Figs 1 and 2). However, it would appear that the low molecular mass, affinity-isolated IRMPs from strains AP7, AP78 and H49 are also easily solubilized during the Sarkosylextraction procedure (Gonzalez et al., 1990) and hence, it would seem reasonable to suggest that in the type strain, the $64 \mathrm{kDa}$ polypeptide is also associated, somehow, with the outer membrane. Although we do not know if the $64 \mathrm{kDa}$ polypeptide can bind transferrin, the $99 \mathrm{kDa}$ polypeptide was the last polypeptide to be eluted from the Sepharose-coupled porcine transferrin (Fig. 2) indicating that it, at least, is capable of direct binding to the host protein.

In summary, the available data (this study; Gonzalez et al., 1990) indicate that while the polypeptides that were affinity-isolated from $A$. pleuropneumoniae could have been isolated in the form of a complex, both are capable of binding porcine transferrin and hence, both have to be considered as receptor candidates. While it is possible that the affinity-isolated polypeptides function as a receptor unit, it is also possible that only one is involved in the initial binding of the transferrin. For example, it is tempting to speculate that in the type strain, the $99 \mathrm{kDa}$ polypeptide represents the porcine transferrin receptor and that the $64 \mathrm{kDa}$ polypeptide represents an associated protein serving an accessory role. Clearly, however, other interpretations are also possible and further studies are required to determine to what extent each of these polypeptides is involved in receptor activity.

This work was supported by operating grants from the Natural Sciences and Engineering Research Council of Canada (NSERC). M.A.R. thanks NSERC for a Postgraduate Scholarship.

\section{References}

Ala'Aldeen, D. A., Davies, H. A., Wall, R. A. \& Borriello, S. P. (1990). The 70 kilodalton iron regulated protein of Neisseria meningitidis is not the human transferrin receptor. FEMS Microbiology Letters 69, 37-42.

ARChibald, F. S. \& DEVoe, I. W. (1979). Removal of iron from human transferrin by Neisseria meningitidis. FEMS Microbiology Letters 6 , 159-162.

ARCHIBALD, F. S. \& DeVoe, I. W. (1980). Iron acquisition by Neisseria meningitidis in vitro. Infection and Immunity 27, 322-334.

Black, J. R., Dyer, D. W., Thompson, M. K. \& Sparling, P. F. (1986). Human immune response to iron-repressible outer membrane proteins of Neisseria meningitidis. Infection and Immunity 54, 710-713.

Blake, M. S. \& Gotschlich, E. C. (1982). Purification and partial characterization of the major outer membrane protein of Neisseria gonorrhoeae. Infection and Immunity 36, 277-283.

BRENER, D., DEVoe, I. W. \& HolbeIN, B. E. (1981). Increased virulence of Neisseria meningitidis after in vitro iron-limited growth at low pH. Infection and Immunity 33, 59-66.

Brown, M. R. W. \& Williams, P. (1985). The influence of environment on envelope properties affecting survival of bacteria in infections. Annual Review of Microbiology 39, 527-556.

Caldwell, M. \& ARChibald, F. (1987). The effect of the hypoferremic response on iron acquisition by and growth of murine lymphoma cells. Biochemistry and Cell Biology 65, 651-657.

Deneer, H. G. \& PotTER, A. A. (1989a). Iron-repressible outermembrane proteins of Pasteurella haemolytica. Journal of General Microbiology 135, 435-443.

DeneER, H. G. \& PotTER, A. A. $(1989 b)$. Effect of iron restriction on the outer membrane proteins of Actinobacillus (Haemophilus) pleuropneumoniae. Infection and Immunity 57, 798-804.

DYeR, D. W., West, E. P. \& Sparling, P. F. (1987). Effects of serum carrier proteins on the growth of pathogenic neisseriae with hemebound iron. Infection and Immunity 55, 2171-2175.

FREY, J. \& NiCOLET, J. (1988). Regulation of hemolysin expression in Actinobacillus pleuropneumoniae serotype 1 by $\mathrm{Ca}^{2+}$. Infection and Immunity 56, 2570-2575.

Gonzalez, G. C., Caamano, D. L. \& Schryvers, A. B. (1990). Identification and characterization of a porcine-specific transferrin receptor in Actinobacillus pleuropneumoniae. Molecular Microbiology 4, 1173-1179.

GRIFFITHS, E. (1987). The iron-uptake systems of pathogenic bacteria. In Iron and Infection; Molecular, Physiological and Clinical Aspects, pp. 69-137. Edited by J. J. Bullen \& E. Griffiths. New York: John Wiley.

Griffiths, E., Stevenson, P. \& Ray, A. (1990). Antigenic and molecular heterogeneity of the transferrin-binding protein of Neisseria meningitidis. FEMS Microbiology Letters 69, 31-36.

HARLOW, E. \& LANE, D. (1988). Silver staining of gels - ammoniacal silver staining. In Antibodies: a Laboratory Manual, pp. 651-652. Cold Spring Harbor NY: Cold Spring Harbor Laboratory.

Herrington, D. A. \& Sparling, P. F. (1985). Haemophilus influenzae can use human transferrin as a sole source for required iron. Infection and Immunity 48, 248-251.

LEE, B. C. \& BRYAN, L. E. (1989). Identification and comparative analysis of the lactoferrin and transferrin receptors among clinical isolates of gonococci. Journal of Medical Microbiology 28, 199-204. 
LEE, B. C. \& SCHRYVERS, A. B. (1988). Specificity of the lactoferrin and transferrin receptors in Neisseria gonorrhoeae. Molecular Microbiology 2, 827-829.

McKenna, W. R., Mickelsen, P. A., Sparling, P. F. \& Dyer, D. W. (1988). Iron uptake from lactoferrin and transferrin by Neisseria gonorrhoeae. Infection and Immunity 56, 785-791.

Martinez, J. L., Delgado-Iribarren, A. \& Baquero, F. (1990). Mechanisms of iron acquisition and bacterial virulence. FEMS Microbiology Reviews 75, 45-56.

Mickelsen, P. A. \& Sparling, P. F. (1981). Ability of Neisseria gonorrhoeae, Neisseria meningitidis, and commensal Neisseria species to obtain iron from transferrin and iron compounds. Infection and Immunity 33, 555-564.

Mickelsen, P. A., Blackman, E. \& Sparling, P. F. (1982). Ability of Neisseria gonorrhoeae, Neisseria meningitidis, and commensal Neisseria species to obtain iron from lactoferrin. Infection and Immunity $35,915-920$.

Mietzner, T. A., Luginbuhl, G. H., SAndstrom, E. \& Morse, S. A. (1984). Identification of an iron-regulated 37,000-Dalton protein in the cell envelope of Neisseria gonorrhoeae. Infection and Immunity 45, 410-416.

MORTON, D. J. \& Williams, P. (1989). Utilization of transferrin-bound iron by Haemophilus species of human and porcine origins. FEMS Microbiology Letters 65, 123-128.

MorTon, D. J. \& Williams, P. (1990). Siderophore-independent acquisition of transferrin-bound iron by Haemophilus influenzae type b. Journal of General Microbiology 136, 927-933.

Niven, D. F., DongA, J. \& ARChIBALD, F. S. (1989). Responses of Haemophilus pleuropneumoniae to iron restriction: changes in the outer membrane protein profile and the removal of iron from porcine transferrin. Molecular Microbiology 3, 1083-1089.

Norqvist, A., Davies, J., Norlander, L. \& Normark, S. (1978). The effect of iron starvation on the outer membrane protein composition of Neisseria gonorrhoeae. FEMS Microbiology Letters 4, 71-75.

NoRrod, P. \& WiLliams, R. P. (1978). Growth of Neisseria gonorrhoeae in media deficient in iron without detection of siderophores. Current Microbiology 1, 281-284.

OAKLEY, B. R., KIRSCH, D. R. \& MORRIS, N. R. (1980). A simplified ultrasensitive silver stain for detecting proteins in polyacrylamide gels. Analytical Biochemistry 105, 361-363.

OgunNariwo, J. A. \& SCHRYVERS, A. B. (1990). Iron acquisition in Pasteurella haemolytica: expression and identification of a bovinespecific transferrin receptor. Infection and Immunity 58, 2091-2097.

O'Reilly, T., Rosendal, S. \& Niven, D. F. (1984). Porcine haemophili and actinobacilli : characterization by means of API test strips and possible taxonomic implications. Canadian Journal of Microbiology 30, 1229-1238.

Peterson, G. L. (1977). A simplification of the protein assay method of Lowry et al. which is more generally applicable. Analytical Biochemistry 83, 346-356.
Pidcock, K. A., Wooten, J. A., Daley, B. A. \& Stull, T. L. (1988) Iron acquisition by Haemophilus influenzae. Infection and Immunity 56, 721-725.

Pohl, S., Bertschinger, H. U., Frederiksen, W. \& Mannheim, W. (1983). Transfer of Haemophilus pleuropneumoniae and the Pasteurella haemolytica-like organism causing porcine necrotic pleuropneumonia to the genus Actinobacillus (Actinobacillus pleuropneumoniae comb. nov.) on the basis of phenotypic and deoxyribonucleic acid relatedness. International Journal of Systematic Bacteriology 33, 510514.

SCHRYVERS, A. B. (1988). Characterization of the human transferrin and lactoferrin receptors in Haemophilus influenzae. Molecular Microbiology 2, 467-472.

SCHRYVERS, A. B. (1989). Identification of the transferrin- and lactoferrin-binding proteins in Haemophilus influenzae. Journal of Medical Microbiology 29, 121-130.

Schryvers, A. B. \& Gonzalez, G. C. (1989). Comparison of the abilities of different protein sources of iron to enhance Neisseria meningitidis infection in mice. Infection and Immunity 57, 24252429.

SCHRYVERS, A. B. \& GonZALEZ, G. C. (1990). Receptors for transferrin in pathogenic bacteria are specific for the host's protein. Canadian Journal of Microbiology 36, 145-147.

SCHR YVERS, A. B. \& LEE, B. C. (1989). Comparative analysis of the transferrin and lactoferrin binding proteins in the family Neisseriaceae. Canadian Journal of Microbiology 35, 409-415.

SCHRYVERS, A. B. \& MoRrIs, L. J. (1988a). Identification and characterization of the transferrin receptor from Neisseria meningitidis. Molecular Microbiology 2, 281-288.

SCHRYVERS, A. B. \& MORRIS, L. J. (1988b). Identification and characterization of the human lactoferrin-binding protein from Neisseria meningitidis. Infection and Immunity 56, 1144-1149.

Sebunya, T. N. K. \& SAUnders, J. R. (1983). Haemophilus pleuropneumoniae infection in swine: a review. Journal of the American Veterinary Medical Association 182, 1331-1337.

Simonson, C., Brener, D. \& DeVoe, I. W. (1982). Expression of a high-affinity mechanism for acquisition of transferrin iron by Neisseria meningitidis. Infection and Immunity 36, 107-113.

TSAI, J., DYeR, D. W. \& SPARling, P. F. (1988). Loss of transferrin receptor activity in Neisseria meningitidis correlates with inability to use transferrin as an iron source. Infection and Immunity 56, 31323138.

West, S. E. H. \& Sparling, P. F. (1985). Response of Neisseria gono: rhoeae to iron limitation: alterations in expression of membrane proteins without apparent siderophore production. Infection and Immunity 47, 388-394.

Williams, P. \& BROWN, M. R. W. (1986). Influence of iron restriction on growth and the expression of outer membrane proteins by Haemophilus influenzae and $H$. parainfluenzae. FEMS Microbiology Letters 33, 153-157. 